\title{
Environmental Impact and Physicochemical Assessment of Pond Ash for its Potential Application as a Fill Material
}

\author{
Manju Suthar ${ }^{1} \cdot$ Praveen Aggarwal $^{1}$
}

Received: 9 March 2016/Accepted: 21 June 2016/Published online: 5 July 2016

(C) Springer International Publishing Switzerland 2016

\begin{abstract}
Thermal power plants (TPPs) produce a large quantity of coal ash, whose disposal is a big environmental issue. A major portion of coal ash is dumped as pond ash in ash pond near TPPs. Properties of pond ash vary from TPP to TPP and also within the same ash pond at inflow and outflow point. To assess the feasibility of pond ash as a fill material, pond ash samples were collected from inflow and outflow points of three TPPs in Haryana. This paper presents a detailed characterization study on the physicochemical, mineralogical and morphological properties of pond ash samples. Leaching study was also carried out to assess the potential contamination of ground water from coal ash fills. Results reveal that all inflow and outflow pond ashes have low specific gravity (2.03-2.27) as compared to soil (2.6-2.7), i.e. natural fill material, low amount of unburned carbon content (1.79-3.49\%) and the values of maximum dry density and optimum moisture content are within the permissible limits as per design standards of embankment construction. The results of leaching study indicate that concentration of lead $(\mathrm{Pb})$ and chromium $(\mathrm{Cr})$ are quite high from standard land disposal limit, prescribed by Ministry of Environment and Forest in all pond ash samples. So it can be effectively used as construction fill materials for low-lying areas and as embankment materials etc., with caution to protect ground water from contamination due to the high concentration of lead $(\mathrm{Pb})$ and chromium $(\mathrm{Cr})$.
\end{abstract}

Manju Suthar

manju.manni4@gmail.com

Praveen Aggarwal

praveen_agg@hotmail.com

1 Department of Civil Engineering, National Institute of Technology, Kurukshetra, Haryana 136119, India
Keywords Pond ash · Physico-chemical-mineralogical properties · Morphological properties · Leaching

\section{Introduction}

Huge quantity of fly ash and bottom ash is generated by thermal power plants (TPPs) as a by-product. About $80 \%$ of the coal ash is in the form of fly ash and rest being bottom ash [1]. For disposal purpose these two types of ashes are mixed together with a large quantity of water, are transported in the form of slurry through pipe and stored in the lagoons, results into ash deposits known as pond ash. This kind of ash disposal system is known as wet disposal system. It is commonly used in India and other parts of the world. Disposal of coal ash this way require million acres of land, which could be used otherwise for agricultural and other purposes. Effective utilization of ash in highway construction shall provide a sustainable solution to the problem of ash disposal. It shall also reduce pressure on natural resources [2].

Characteristics of ash produced from a thermal power plant depend on the coal source, coal pulverization, boiler type and ash collection device [3, 4]. Good amount of work has been carried out on fly ash and bottom ash as compared to pond ash. Hardly any study is available on physicochemical, mineralogical and leachate characteristics of pond ash at inflow point and outflow point.

Wet disposal system causes segregation of ash mixture and results in two distinctly different types of materials at inflow and outflow points within the same ash pond, which are significantly different from both fly ash and bottom ash. Coarser and heavier particles of ash, settle down near the inflow point. Finer and lighter ash particles are carried away and settle near the outflow point [5-9]. Therefore, it 
is essential to characterize the pond ash, before utilization as construction fill materials for low-lying areas and as embankment materials.

The objective of the study is to understand the variability in the composition of the pond ash at inflow and outflow points. In the present study a complete characterization, i.e., physical, chemical, mineralogical and morphological properties of inflow and outflow point, pond ash samples, collected from three prominent TPPs in Haryana was carried out. Leachate analysis was also carried out, to understand the adverse impact on the environment, particularly ground water.

\section{Materials and Methods}

\section{Materials Used}

In order to understand possible variation in the properties of pond ash samples from inflow and outflow points, samples were collected from inflow and outflow points of three TPPs of Haryana, India i.e. Khedar, Panipat and Yamunanagar. Figure 1 shows inflow and an outflow point from Panipat ash pond (wet disposal). For easy identification pond ash samples collected from Khedar, Panipat and Yamunanagar ash ponds are indicated as KP, PP and YP respectively. Inflow and outflow samples are marked with ' $\mathrm{I}$ ' and ' $\mathrm{O}$ ' accordingly.

\section{Characterization Methods}

In order to characterize various pond ash samples their physical, chemical, mineralogical, morphological and leachate properties were tested in the present study.

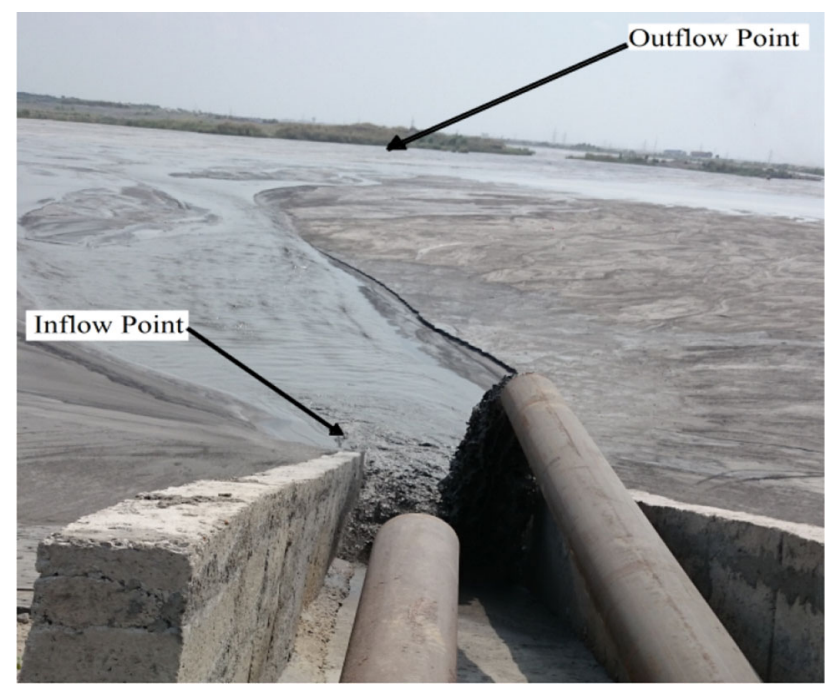

Fig. 1 Inflow and an outflow point from Panipat ash pond
Important physical properties of a material to be used as fill material include particle size analysis, specific gravity $(G)$, bulk density $(\rho)$, porosity $(n)$, maximum dry density (MDD) and optimum moisture content (OMC). Particle size analysis was carried out using sieves and hydrometer. Samples were sieved through sieves of standard size i.e. $4.75,2.0,1.18,1.0,0.600,0.425,0.300,0.212,0.150$ and $0.075 \mathrm{~mm}$. The hydrometer test was performed on fine grained ash fraction, collected in pan, passing through $0.075 \mathrm{~mm}$ sieve. The specific gravity $(G)$ of ash samples were determined by pycnometer bottle. Bulk density $(\rho)$ was measured using proctor mould having $100 \mathrm{~mm}$ diameter and $127.3 \mathrm{~mm}$ height (1000 $\mathrm{ml}$ capacity). As there was no standard procedure for compaction, in the present study oven dried samples were compacted using the vibratory table for $30 \mathrm{~s}$ to find out the bulk density of ash samples. The porosity $(n)$ of the ash samples were calculated using following relationship:

$n=(1-\rho / G) \times 100 \%$

where $n$ is the porosity of ash sample, $\rho$ is the bulk density of ash sample, $G$ is the specific gravity of ash sample.

Standard proctor compaction test was carried out as per IS: 2720-Part 7 [10] on ash samples to determine the OMC and MDD.

The chemical compositions of ash samples were identified by wavelength dispersive-X-ray fluorescence (WDXRF) setup (model no. S8 Tiger, Germany). The loss on ignition (LOI) test was performed as per IS: 1917 Part 1 [11]. Oven dried ash samples were used for the tests. The temperature of muffle furnace was increased gradually up to a temperature of $1000{ }^{\circ} \mathrm{C}$. JEOL JSM-6510LV type scanning electron microscope (SEM) system was used to examine the morphology of the particles. During testing, ash particles were coated with a thin layer of gold-palladium alloy using a JEOL JFC-1600 auto fine coater to make them good conductor. The mineralogical characteristic was determined with an X-ray diffraction (XRD) spectrometer. The samples were scanned over a scattering angle $2 \theta$ of $10^{\circ}-70^{\circ}$. Joint Committee on Powder Diffraction Standards (JCPDS) data files were used to identify the crystalline phases and comparing the peak positions.

\section{Leaching Test}

The pond ash samples were tested for heavy metals likechromium $(\mathrm{Cr})$, manganese $(\mathrm{Mn})$, lead $(\mathrm{Pb})$, zinc $(\mathrm{Zn})$, copper $(\mathrm{Cu})$, nickel $(\mathrm{Ni})$ and cobalt $(\mathrm{Co})$. In this study, the standard test method, namely toxicity characteristic leaching procedure (TCLP)-1311 was used to investigate the leaching behavior of the ash samples. 
In order to perform the test, an extraction fluid was prepared by adding $5.7 \mathrm{ml}$ glacial acetic acid to $500 \mathrm{ml}$ of distilled water. Further, $1(\mathrm{~N}) \mathrm{NaOH}$ was added in the solution and the final solution was made to 11 by adding additional distilled water. During this process, $\mathrm{pH}$ value of this solution was maintained at 4.94. Crushed sample of $100 \mathrm{~g}$ was added to this solution (acetic acid-NaOH buffer solution) in a 21 polyurethane bottle. After that, for TCLP test, 11 of appropriate solution was added into the bottle. Then, the bottle was horizontally shaken at $30 \mathrm{rpm}$ in an oscillating shaker for $18 \mathrm{~h}$ at $25^{\circ} \mathrm{C}$. After shaking, the mixture was allowed to settle for $5 \mathrm{~min}$, and then the liquid phase was decanted known as leachate. The $\mathrm{pH}$ of the leachate was determined immediately after collection. The leachate was filtered through a $0.45 \mathrm{~mm}$ filter paper by vacuum filtration system. The sampling bottle was preserved in order to avoid the volume change and evaporation. Elements concentration in the leachate was determined by using MP-atomic emission spectrophotometer (MP-AES).

\section{Results and Discussion}

\section{Particle Size Distribution (PSD)}

The results of particle size distribution (PSD) of all pond ash samples are shown in Fig. 2. Coefficient of uniformity $\left(C_{u}\right)$ and coefficient of curvature $\left(C_{c}\right)$ are calculated using following relationship and are reported in Table 1.

$C_{u}=D_{60} / D_{10}$

$C_{c}=\left(D_{30}\right)^{2} /\left(D_{60} \times D_{10}\right)$

where $D_{10}, D_{30}$ and $D_{60}$ are particle size such that 10,30 and $60 \%$ of the ash is finer than these sizes, respectively.

Results of the PSD are shown in Table 1. From the results, it is observed that all the inflow ash samples are uniformly graded and all outflow ash samples are well graded in nature. Out of these, inferences can be made that inflow ash samples may be suitable for drainage layer being uniformly graded and outflow ash samples are better fill material being well graded in nature.

All inflow ash samples have the major component of fine sand size i.e. $(0.425-0.075 \mathrm{~mm})$. For Khedar and Yamunanagar, outflow samples have the major component of silt size $(0.075-0.002 \mathrm{~mm})$.

\section{Specific Gravity, Bulk Density and Porosity}

The results of specific gravity $(G)$, bulk density $(\rho)$ and porosity $(n)$ are also shown in Table 1 . The specific gravity of coal ash is reported to lie between 1.66 and 2.86 [12]. The reason for low specific gravity could be due to the presence of a large number of hollow cenospheres from which entrapped air cannot be removed [13]. Specific gravity obtained for inflow and outflow pond ash samples lies between 2.21-2.27 and 2.03-2.06 respectively. However, the specific gravity values of all the ash samples are considerably below the soils i.e. natural fill material. Inflow ash samples have higher specific gravity may be due to the presence of higher $\mathrm{Fe}_{2} \mathrm{O}_{3}$ content $(8.70-11.48 \%)$ than outflow ash samples $(4.35-5.95 \%)$ as obtained from the chemical analysis. The bulk density of ash samples from inflow and outflow point ranges between 1.114-1.275 g/cc and $1.081-1.223 \mathrm{~g} / \mathrm{cc}$, respectively. The porosity is calculated from bulk density using Eq. (1). The porosity of inflow ash samples range between 43.83 and 50.04\% whereas for outflow ash samples range between $39.75-47.52 \%$. Because of uniform gradation of inflow ash samples, their porosity is higher as compared to outflow ash samples.

\section{Compaction Characteristics}

The results of compaction test are also shown in Table 1 . From the compaction test results, it is observed that the MDD of the inflow and outflow ash samples range from $1.212-1.322 \mathrm{~g} / \mathrm{cc}$ to $1.093-1.312 \mathrm{~g} / \mathrm{cc}$; OMC range from $18.01-28.3$ to $18.6-32.2 \%$, respectively. Results of the MDD and OMC for all the ash samples are within the permissible limits (MDD- 0.9-1.6 g/cc and OMC18.0-38 \%) as specified by IRC:SP:58-2001 [14] for suitability of ash in embankment construction.

\section{Chemical Composition}

The chemical composition of all pond ash samples are presented in Table 2. From the results, it is observed that all pond ash samples are primary rich in silica $\left(\mathrm{SiO}_{2}\right)$, alumina $\left(\mathrm{Al}_{2} \mathrm{O}_{3}\right)$ and iron oxide $\left(\mathrm{Fe}_{2} \mathrm{O}_{3}\right)$. They also contain a small amount of $\mathrm{CaO}, \mathrm{TiO}_{2}, \mathrm{P}_{2} \mathrm{O}_{5}, \mathrm{~K}_{2} \mathrm{O}, \mathrm{MgO}, \mathrm{MnO}$, $\mathrm{Na}_{2} \mathrm{O}$ and $\mathrm{SO}_{3}$. In inflow ash samples, the amount of $\mathrm{SiO}_{2}$ vary from 61.77 to $65.95 \%, \mathrm{Al}_{2} \mathrm{O}_{3} 20.56$ to $21.64 \%$, $\mathrm{Fe}_{2} \mathrm{O}_{3} 8.70$ to $11.48 \%$ and $\mathrm{CaO}$ from 0.76 to $1.12 \%$. In the case of outflow ash samples, amount of $\mathrm{SiO}_{2}$ vary from 62.45 to $63.85 \%, \mathrm{Al}_{2} \mathrm{O}_{3} 25.03$ to $27.77 \%, \mathrm{Fe}_{2} \mathrm{O}_{3} 4.35$ to $5.95 \%$ and $\mathrm{CaO}$ from 0.66 to $0.90 \%$. Mishra and Das [15] reported that higher amount of $\mathrm{SiO}_{2}$ content $(\geq 60 \%$ of the total composition) in ash sample may help in increasing the strength of filling material and offer better bearing capacity. Due to the presence of small amount of free lime content $(<1 \%)$, the ash samples possess very negligible pozzolanic or cementing properties. 

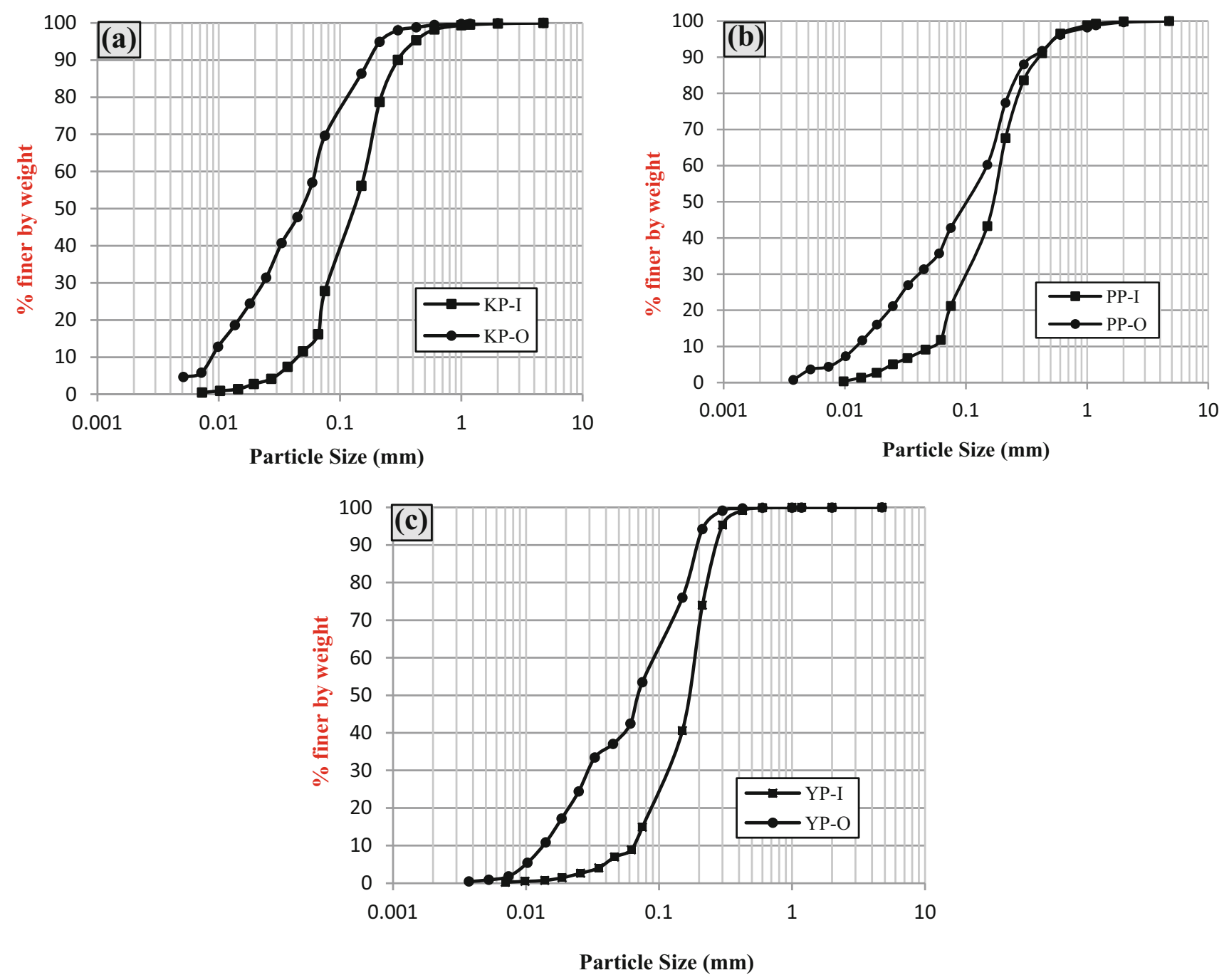

Fig. 2 PSD curves for pond ash samples from a Khedar (KP-I and KP-O), b Panipat (PP-I and PP-O), c Yamunanagar (YP-I and YP-O)

According to ASTM C 618-08a [16], the pond ash samples fall in the category of class- $\mathrm{F}$ ash; since the combined amount of silica, alumina and iron oxides are more than $70 \%$ and the $\mathrm{CaO}$ percentage is less than $5 \%$. Results of the chemical characterization are found to be in agreement with the results of the study conducted by Jakka et al. [9] on inflow and outflow point pond ash samples from same ash pond. From the analysis of the results shown in Table 2 it is observed that, there is slight variation in the chemical composition of inflow and outflow ash samples, which may be because of various reasons that include(i) chemical soluble in nature may have different concentration at inflow and outflow point (ii) ash at the outflow point may be of coal used long back which may be different from the coal used presently producing pond ash at inflow point.

It is clear from Table 2 that the LOI values (i.e. unburned carbon) of the samples from the inflow point are higher than samples from outflow point for all ash ponds, indicating that fine ash has lower carbonaceous matter or presence of unburned carbon makes the sample heavier. The LOI values for all the ash samples are less than $5.0 \%$ i.e. maximum prescribed limit as per ASTM C618-08a [16]. Due to low LOI value, there is no risk of self heating or spontaneous heating if pond ash is utilized as a filling material.

\section{Morphology Analysis}

The SEM micrographs of the pond ash are presented in Figs. 3 and 4 for inflow and outflow ash samples at two different magnifications i.e. $\times 150$ and $\times 1000$. From Fig. 3a-f, it is observed that inflow ash particles are irregular in shape with complex pore structure. Further at higher magnifications, it is noticed that there is an agglomeration of smaller ash particles into different shapes 
Table 1 Physical properties of pond ash samples

\begin{tabular}{lllllll}
\hline Properties & KP-I & KP-O & PP-I & PP-O & YP-I & YP-O \\
\hline Particle size distribution (PSD) $(\%)$ & & & & & & \\
Coarse sand size $(4.75-2.0 \mathrm{~mm})$ & 0.17 & 0.08 & 0.12 & 0.35 & 0.00 & 0.06 \\
Medium sand size $(2.0-0.425 \mathrm{~mm})$ & 4.48 & 1.11 & 8.78 & 7.90 & 0.83 & 0.21 \\
Fine sand size $(0.425-0.075 \mathrm{~mm})$ & 67.57 & 29.20 & 69.92 & 48.97 & 84.30 & 46.27 \\
Silt $(0.075-0.002 \mathrm{~mm})$ & 27.78 & 69.61 & 21.18 & 42.78 & 14.87 & 53.46 \\
$D_{10}, \mathrm{~mm}$ & 0.047 & 0.009 & 0.060 & 0.014 & 0.067 & 0.015 \\
$D_{30}, \mathrm{~mm}$ & 0.080 & 0.024 & 0.120 & 0.044 & 0.130 & 0.030 \\
$D_{60}$, mm & 0.160 & 0.064 & 0.200 & 0.150 & 0.190 & 0.091 \\
Uniformity co-efficient $\left(C_{u}\right)$ & 3.40 & 7.11 & 3.33 & 10.70 & 2.84 & 6.07 \\
Co-efficient of curvature $\left(C_{c}\right)$ & 0.85 & 1.00 & 1.20 & 0.92 & 1.33 & 0.66 \\
Colour & Grey & Grey & Dark grey & Dark grey & Grey & Grey \\
Specific gravity $(G)$ & 2.27 & 2.03 & 2.23 & 2.06 & 2.21 & 2.05 \\
Bulk density $(\rho)$, g/cc & 1.275 & 1.223 & 1.114 & 1.081 & 1.186 & 1.185 \\
Porosity $(n), \%$ & 43.83 & 39.75 & 50.04 & 47.52 & 46.33 & 42.20 \\
MDD $(\mathrm{g} / \mathrm{cc})$ & 1.322 & 1.312 & 1.290 & 1.175 & 1.212 & 1.093 \\
OMC $(\%)$ & 18.01 & 18.6 & 24.5 & 26.8 & 28.3 & 32.2 \\
\hline
\end{tabular}

\begin{tabular}{lrrrrrr}
\hline $\begin{array}{l}\text { Major elements } \\
\text { (as oxides) }\end{array}$ & KP-I & KP-O & PP-I & PP-O & YP-1 & YP-O \\
\hline $\mathrm{SiO}_{2}$ & 61.77 & 63.85 & 65.95 & 63.36 & 64.72 & 62.45 \\
$\mathrm{Al}_{2} \mathrm{O}_{3}$ & 21.64 & 26.67 & 20.56 & 25.03 & 21.31 & 27.77 \\
$\mathrm{Fe}_{2} \mathrm{O}_{3}$ & 11.48 & 4.35 & 8.76 & 5.95 & 8.70 & 4.45 \\
$\mathrm{SiO}_{2}+\mathrm{Al}_{2} \mathrm{O}_{3}+\mathrm{Fe}_{2} \mathrm{O}_{3}$ & 94.89 & 94.87 & 95.27 & 94.34 & 94.73 & 94.67 \\
$\mathrm{CaO}$ & 1.12 & 0.90 & 0.79 & 0.90 & 0.76 & 0.66 \\
$\mathrm{TiO}_{2}$ & 1.36 & 1.69 & 1.23 & 1.58 & 1.24 & 1.78 \\
$\mathrm{P}_{2} \mathrm{O}_{5}$ & 0.33 & 0.30 & 0.33 & 0.40 & 0.37 & 0.50 \\
$\mathrm{~K}_{2} \mathrm{O}$ & 1.00 & 0.93 & 1.29 & 1.64 & 1.80 & 1.43 \\
$\mathrm{MgO}_{\mathrm{MnO}}$ & 0.65 & 0.49 & 0.55 & 0.57 & 0.60 & 0.45 \\
$\mathrm{Na}_{2} \mathrm{O}$ & 0.15 & 0.04 & 0.10 & 0.07 & 0.10 & 0.05 \\
$\mathrm{SO}_{3}$ & 0.13 & 0.26 & 0.06 & 0.07 & 0.09 & 0.08 \\
$\mathrm{LOI}$ & 0.11 & 0.19 & 0.15 & 0.16 & 0.08 & 0.09 \\
\hline
\end{tabular}

Table 2 Chemical composition of pond ash samples (\%) with the rough surface. From Fig. $4 \mathrm{a}-\mathrm{f}$, it is observed that some of the larger outflow particles of ash are cluster of smaller spherical particles. Further at higher magnifications, it is noticed that the ash particles from outflow point are spherical with varying sizes and their surface is smooth, as compared to ash particles from inflow point. These findings are compatible with the PSD of inflow and outflow ash samples (Fig. 1).

\section{Mineralogy Analysis}

X-ray powder diffraction (XRD) results are presented in Fig. 5a, b. From the results, it is observed that all ash samples primarily contain quartz $\left(\mathrm{SiO}_{2}\right)-\mathrm{Q}$ and mullite $\left(\mathrm{Al}_{6} \mathrm{Si}_{2} \mathrm{O}_{13}\right)-\mathrm{M}$ as main mineralogical phases with a certain amount of iron oxide [magnetite $\left(\mathrm{Fe}_{3} \mathrm{O}_{4}\right)$-Ma and hematite $\left.\left(\mathrm{Fe}_{2} \mathrm{O}_{3}\right)-\mathrm{H}\right]$. These crystalline minerals are non-reactive at ordinary temperature; their presence in large proportion tends to reduce their reactivity. Thus, these ashes practically behave as an inert material [17]. Quartz has a relatively high melting point of $1400{ }^{\circ} \mathrm{C}$, so most of it remains in the coal ash. The structural breakdown of minerals like kaolinite (and other clay minerals) and iron-bearing minerals like pyrite and siderite give rise to various high temperature phases such as iron oxides and aluminosilicates $[18,19]$. From the XRD test results, it is observed that inflow ash samples are much more crystalline (high intensity of peaks) because of coarser particle size than outflow ash samples, but both (inflow and outflow ash) contain almost similar crystalline phases. The results are in 
Fig. 3 SEM of inflow ash samples
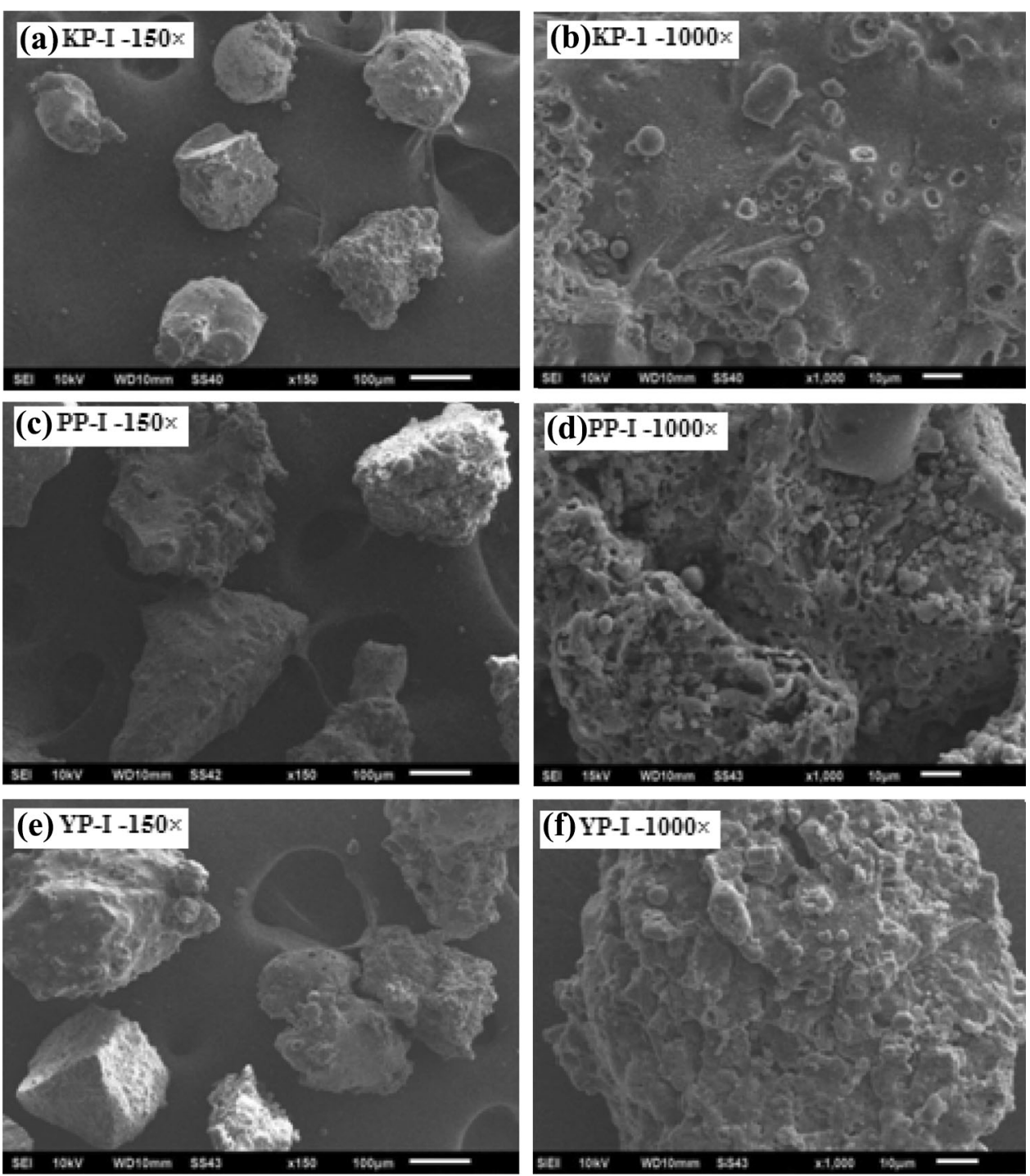

agreement with Chung and Smith [20], they observed XRD pattern of the clinker type bottom ashes as much more crystalline than fly ash sample, but both contains many of the same crystalline phases. Ouartz $(\mathrm{SiO} 2)$ is the major crystalline phase in the PP-1 and it is in accordance with high $\mathrm{SiO}_{2}$ content as per chemical composition, similar observation was reported by Yilmaz [21].

\section{Leachate Analysis}

Results of the leachate test are presented in Table 3 along with the permissible limiting values as prescribed by Ministry of Environment \& Forests (MoEF) for standard land disposal in surface water and public sewer. The leaching of lead $(\mathrm{Pb})$ is observed $<1.0 \mathrm{mg} / \mathrm{l}$ in all ash samples which is quite high from the standard land disposal limit in surface water but less than the prescribed limit for disposal in the public sewer. The leaching of chromium
(Cr) is observed $<3.0 \mathrm{mg} / \mathrm{l}$ in all ash samples which is also quite high from the standard land disposal limit of surface water and public sewer, necessitating appropriate treatment before disposal/usage.

The leaching of cobalt (Co) is $<3.0 \mathrm{mg} / \mathrm{l}$ in all ash samples. Leaching of manganese $(\mathrm{Mn})$ in ash samples from inflow point ranges between 1.85 and $4.07 \mathrm{mg} / \mathrm{l}$ and for outflow point it ranges between 2.39 and $3.71 \mathrm{mg} / \mathrm{l}$, no permissible limit is provided by MoEF. The leaching of zinc $(\mathrm{Zn})$, copper $(\mathrm{Cu})$ and nickel $(\mathrm{Ni})$ are found within permissible limits as prescribed by the MoEF, Govt. of India.

\section{Conclusions}

Based on results and discussion mentioned above, the following conclusions can be drawn: 
Fig. 4 SEM of outflow ash samples
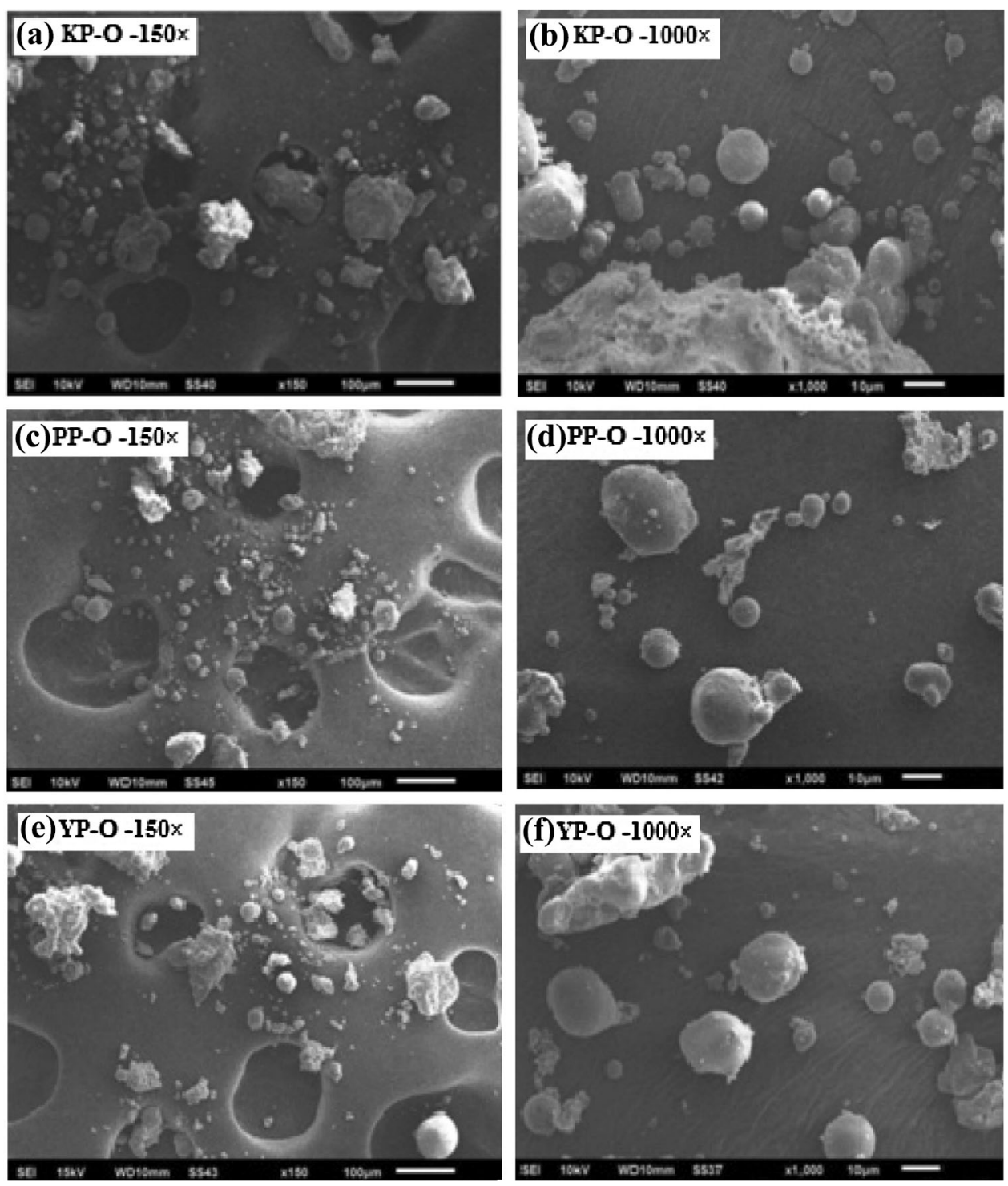
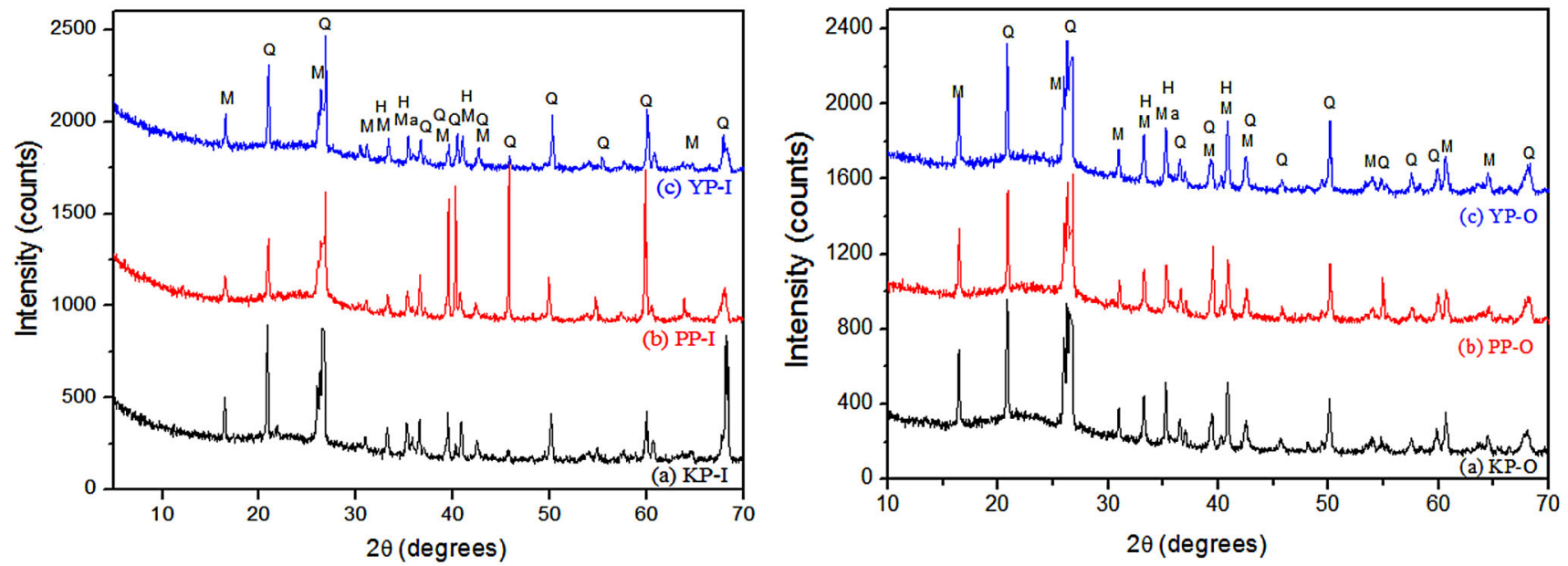

Fig. 5 a XRD results for inflow point ash sample $a$ KP-I $b$ PP-I $c$ YP-I. b XRD results for outflow point ash sample $a$ KP-O $b$ PP-O $c$ YP-O 
Table 3 Leachate analysis of pond ash samples (values in $\mathrm{mg}$ / 1)

\begin{tabular}{|c|c|c|c|c|c|c|c|c|}
\hline \multirow[t]{2}{*}{ Trace elements } & \multirow[t]{2}{*}{ KP-I } & \multirow[t]{2}{*}{ KP-O } & \multirow[t]{2}{*}{ PP-I } & \multirow[t]{2}{*}{ PP-O } & \multirow[t]{2}{*}{ YP-1 } & \multirow[t]{2}{*}{ YP-O } & \multicolumn{2}{|c|}{$\begin{array}{l}\text { Standards* (land disposal) } \\
\text { (as per mode of disposal) }\end{array}$} \\
\hline & & & & & & & Surface water & Public sewer \\
\hline Lead $(\mathrm{Pb})$ & $<1.0$ & $<1.0$ & $<1.0$ & $<1.0$ & $<1.0$ & $<1.0$ & 0.1 & 1.0 \\
\hline Chromium (Cr) & $<3.0$ & $<3.0$ & $<3.0$ & $<3.0$ & $<3.0$ & $<3.0$ & 2.0 & 2.0 \\
\hline Cobalt (Co) & $<3.0$ & $<3.0$ & $<3.0$ & $<3.0$ & $<3.0$ & $<3.0$ & NR & NR \\
\hline Manganese (Mn) & 4.07 & 3.71 & 3.88 & 2.39 & 1.85 & 2.60 & NR & NR \\
\hline Zinc $(\mathrm{Zn})$ & 1.90 & 2.92 & 1.22 & 0.70 & 1.07 & 1.11 & 5 & 15 \\
\hline Copper $(\mathrm{Cu})$ & $<0.5$ & $<0.5$ & $<0.5$ & $<0.5$ & $<0.5$ & $<0.5$ & 3.0 & 3.0 \\
\hline Nickel (Ni) & $<1.0$ & $<1.0$ & $<1.0$ & $<1.0$ & $<1.0$ & $<1.0$ & 3.0 & 3.0 \\
\hline
\end{tabular}

$N R$ Not reported

* Standards as given in (land disposal) as in Govt. of India MoEF notification, 25th September 2000
- Particle size analysis depicts most of the particles of inflow ash samples are of fine sand size and outflow ash samples are of fine silt size. All outflow ash samples shall be better fill material being well graded in nature whereas inflow ash samples may be suitable for drainage layer being of uniformly graded in nature.

- Pond ash samples show low specific gravity value ranges from 2.03 to 2.27 due to the presence of hollow cenospheres. However, inflow ash samples have higher specific gravity as compared to outflow ash samples. The low specific gravity of pond ashes is advantageous to use as fill materials because it shall exert lesser earth pressure.

- From chemical analysis result, it is observed that the combined amount of silica, alumina and iron oxides are more than $70 \%$ in all ash samples, hence as per ASTM C618-08a, the pond ash samples are classified as class F ash.

- There is no risk of spontaneous heating if pond ash samples are used as fill material because of the low amount of unburned carbon content, LOI being $<5.0 \%$.

- Compaction characteristics show that, inflow ash samples have higher MDD than outflow ash samples. It is mainly due to the higher specific gravity value of inflow ash samples. Results of the MDD and OMC for all the ash samples are within the permissible limits as specified by IRC:SP:58-2001 for suitability of ash in embankment construction.

- The morphology characteristics revealed that the particles from outflow point are spherical in shape and smooth surfaced as compared to ash particles from inflow point, which are irregular in shape with rough surface.

- Quartz-Q and mullite-M are the most predominant minerals present in all ash samples, as indicated by XRD analysis.
- From leachate analysis, it is observed that the leaching of $\mathrm{Pb}$ is $<1.0 \mathrm{mg} / \mathrm{l}$ in all ash samples, which is quite high from the standard land disposal limit in surface water. Leaching of $\mathrm{Cr}$ is $<3.0 \mathrm{mg} / \mathrm{l}$ which also quite high from the standard land disposal limit in surface water and public sewer as prescribed by MoEF. The higher concentrations of $\mathrm{Pb}$ and $\mathrm{Cr}$ in ash samples may contaminate ground water table if the ash is disposed directly without proper testing and treatment.

From the results, it can be summarized that pond ash has a great potential as fill material. Higher concentration of heavy metals such as $\mathrm{Pb}$ and $\mathrm{Cr}$ need to be checked before their use as fill material in order to protect ground water table.

\section{References}

1. Sarkar A, Rano R, Mishra KK, Sinha IN (2005) Particle size distribution profile of some Indian fly ash-a comparative study to assess their possible uses. Fuel Process Technol 86(11):1221-1238

2. Suthar M, Aggarwal P (2015) Class- F pond ash a potential highway construction material- a review. Ind Highw IRC 43(8):23-32

3. Gupta RP, Wall TF, Kajigaya I, Miyamae S, Tsumita Y (1998) Computer-controlled scanning electron microscopy of minerals in coal-implications for ash deposition. Prog Energy Combust Sci 24(6):523-543

4. Sarkar A, Rano R, Udaybhanu G, Basu AK (2006) A comprehensive characterization of fly ash from a thermal power plant in Eastern India. Fuel Process Technol 87(3):259-277

5. Bross B (1981) Pollution from ash lagoons and use of ash for embankments. In: Proceedings of the 10th international conference on soil mechanics and foundation engineering, Stockholm, pp 309-312.

6. Skarzynska KM, Rainbow AKM, Sawisza E (1989) Characteristics of ash in storage ponds. In: Proceedings of the 12th international conference on soil mechanics and foundation engineering, Rio de Janerio, pp 1915-1918. 
7. Datta M, Singh A, Kaniraj R (1996) Spatial variation of ash characteristics in an ash pond. In: Raju VS et al (eds) Ash pond and ash disposal systems. Narosa Publishers, Delhi, pp 111-119

8. Sridharan A, Pandian NS, Rajasedhar C (1996) Geotechnical characterization of pond ash. In: Raju VS et al (eds) Ash pond and ash disposal systems. Narosa Publishers, Delhi, pp 97-110

9. Jakka RS, Ramana GV, Datta M (2010) Shear behaviour of loose and compacted pond ash. Geotech Geol Eng 28(6):763-778

10. IS 2720 Part 7 (1980) Methods of test for soils-determination of water content-dry density drelation using light compaction. Bureau of Indian Standards, New Delhi

11. IS 1917 Part 1 (1991) Chemical analysis of quartzite and high silica sand-determination of loss on ignition. Bureau of Indian Standards, New Delhi

12. Asokan P, Saxena M, Asolekar SR (2005) Coal combustion residues-environmental implications and recycling potentials. Resour Conserv Recycl 43(3):239-262

13. Pandian NS, Rajasekhar C, Sridharan A (1998) Studies of the specific gravity of some Indian coal ashes. J Test Eval 26(3):177-186
14. IRC SP 58 (2001) Guidelines for use of Fly Ash in road embankments. Indian Road Congress, New Delhi

15. Mishra DP, Das SK (2010) A study of physico-chemical and mineralogical properties of Talcher coal fly ash for stowing in underground coal mines. Mater Charact 61(11):1252-1259

16. ASTM C618-08a (2008) Standard specification for coal fly ash and raw or calcined natural pozzolan for use in concrete. Annual book of ASTM standards. ASTM C618-08a, West Conshohocken

17. Trivedi A, Sud VK (2002) Grain characteristics and engineering properties of coal ash. Granul Matter 4(3):93-101

18. Huffman GP, Huggins FE (1986) Mineral matter and ash in coal. In: Vorres KS (ed) ACS symposium series 301, pp 100-113.

19. Raask E (1986) Mineral matter and ash in coal. In: Vorres KS (ed) ACS symposium series 301, pp 139-155.

20. Chung FH, Smith DK (2014) Industrial applications of X-ray diffraction. Taylor and Francis, book no-13:978-0-8247-1992-0, pp 566-567.

21. Ylmaz H (2015) Characterization and comparison of leaching behaviors of fly ash samples from three different power plants in Turkey. Fuel Process Technol 137:240-249 